\title{
Characterization of Sulphides Patches from the Neyveli Lignite Deposit
}

\author{
D.S. Rao ${ }^{1}$, R. Nagendra ${ }^{2}$, E. Rasool Mohideen ${ }^{3}$ and B.R. Nayak ${ }^{4}$ \\ ${ }^{1}$ NML-MC, CSIR Madras Complex, Taramani, Chennai-600 113 \\ ${ }^{1}$ Present address, Mineralogy Department, IMMT, Bhubaneswar-751 013 \\ ${ }^{2}$ Centre for Geoscience and Engineering, Anna University, Chennai-600 025 \\ ${ }^{3}$ Dept. of Civil Engineering, Crescent Engineering College, Chennai - 600048 \\ ${ }^{4}$ MNP Division, National Metallurgical Laboratory, Jamshedpur - 831007 \\ *Corresponding Author: nmldsr@yahoo.co.in
}

\begin{abstract}
The mineralogy and mineral chemistry of the hard, compact and heavy sulphide patches, found along with lignites of Neyveli, Tamilnadu, India was investigated by optical and electron probe microanalysis. These sulphide boulders consist mostly of marcasite, pyrite and rarely pyrrhotite. Presence of gold in rare and trace quantities from the marcasite of these sulphide patches is reported here for the first time. If this gold content evaluated properly and recovered economically and in an environmental friendly way it adds up to the revenue of the mining company as well as stop the environmental degradation. If marcasite is left as waste, then it may add up to the environment as acid mine drainage.
\end{abstract}

Key words: Marcasite, Lignite, Neyveli, Mineral chemistry

\section{INTRODUCTION}

The main Neyveli lignite field is situated between $11^{\circ} 13^{\prime}-11^{\circ} 38^{\prime} \mathrm{N}$ Latitude and $79^{\circ} 24^{\prime}-79^{\circ} 33^{\prime}$ East Longitude. It extends over a distance of 44 kilometers in N-S direction and 12 kilometers in E-W direction. This lignite deposit forms a part of the Cuddalore Formation of Late Miocene age and are associated with argillaceous and ferruginous sandstone and beds of clay. Neyveli Lignite Corporation Limited is engaged in mining of lignite from its two mines (Mine I and Mine II) which in turn used for thermal power generation in its two captive power stations. Open cast mining is being adopted in Neyveli for exploration of lignite. Lignite being a lower ranking coal 
is characterized by high moisture as well as volatile matter and lower heating values in comparison to high ranking coals. Above all this Neyveli liginite also varies widely in its sulphide sulphur content. Sulphur from these sulphides creates multifold problems during combustion in boilers leading to slagging, fauling, corrosion and of course environmental pollution. It is generally assumed that the sulphur could be present in coal as pyritic sulphur or sulphate sulphur or organic sulphur (Banerjee et al., 1997) all of which behave in different manner during combustion in the boilers/power plants.

\section{SULPHIDES}

In the Neyveli lignite mines lignite is contaminated with sulphides. These sulphides are mostly pale bronze yellow to greenish yellow in colour, heavy as well as non-magnetic in nature; hardness varies from 6 to 7 and with a compressive strength of around $82 \mathrm{~N} / \mathrm{mm}^{2}$ (Kompella and Raghuthaman, 2002). The sulphides present in these mines as boulders, lenticular masses, nodules, veins, platty, wedge shaped lenticular masses and massive concretionary forms with size range of $2-3 \mathrm{~cm}$ to around $20-25 \mathrm{~cm}$. The percentage of these sulphide boulders in the run of mine sample is around 1.97\% (Kompella and Raghuthaman, 2002). These sulphides differ in size, shape and quantities from place to place in the mine, sporadic occurrence in nature and mostly confined to the Mine II. These sulphides cause extensive damage to the mining machineries as well as milling systems as these have high hardness as well as compressive strength and when admitted into the furnance reduces ash fusion temperature and cause slag formation which in turn affects boiler efficiency.

\subsection{Microscopic Studies}

Microscopic studies on the sulphide samples indicated that the sample consists of mostly marcasite, rarely pyrite and pyrrhotite and quartz as the major silicate only. The size of the sulphide grains are highly variable and present as veins, disseminations, irregular and subangular grains showing yellow to yellowish white colour and high reflectivity. Well developed pyrite crystals are rarely observed. Pyrrhotite is present in these sulphids and observed rarely (Fig.1). Quartz is in the size range of 20-300 microns. The quartz grain mostly present as subhedral, subangular and highly irregular shapes. Many of these quartz grains show undulose extinction and are fractured indicating effect of stress and strain. Occasionally the silicates contain pyrite as inclusions and vice-versa.

\subsection{XRD Studies}

X-ray diffraction (Fig.2) studies of the sulphide patches indicate that these are marcasite and quartz only. 


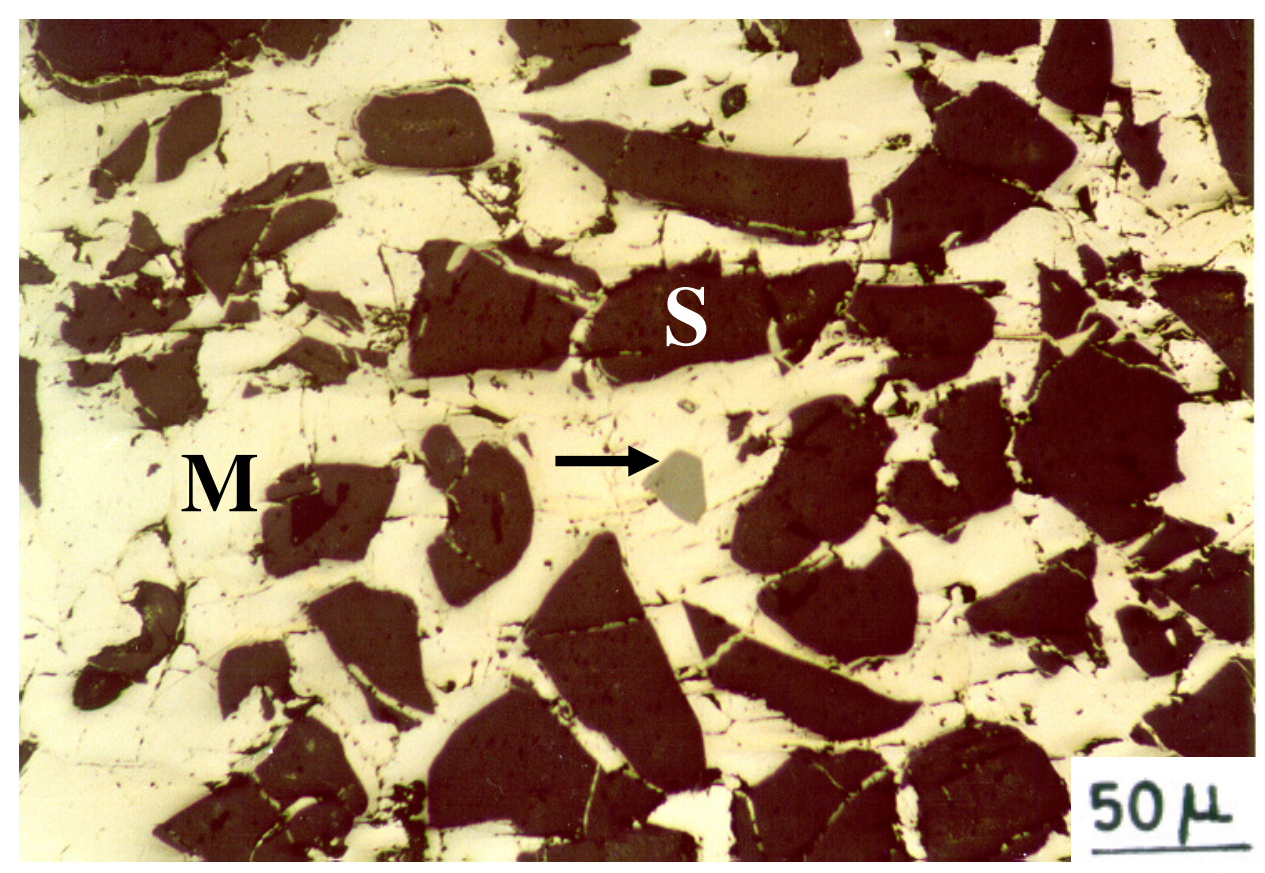

Fig.1. Marcasite enclosing various shapes and sizes of silicates (S) and a grain of pyrrhotite (shown by arrow mark).

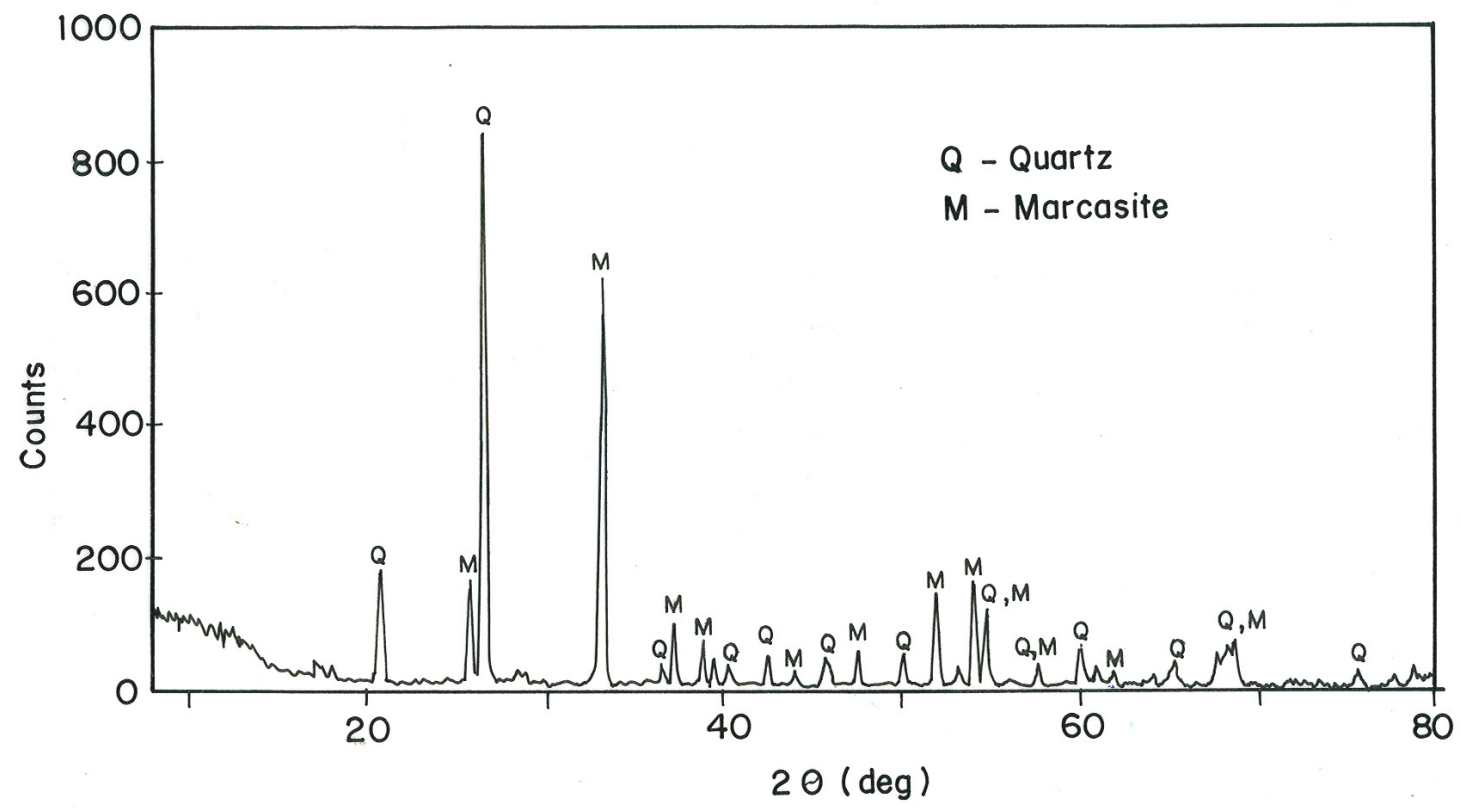

Fig.2. XRD of the marcasite sample. 


\subsection{Chemistry of These Sulphides}

The typical bulk chemical composition of these sulphide boulders is given in Table 1 (Kompella and Raghuthaman, 2002). From the bulk chemical composition it can be inferred that the sulphide boulders are nothing but iron sulphide which could be pyrite and/or marcasite as mentioned by Kompella and Rahuthaman, (2002).

Table 1. Bulk chemical composition of the sulphides from Neyveli lignite

\begin{tabular}{|l|l|}
\hline Compounds & In wt.\% \\
\hline $\mathrm{SiO}_{2}$ & 0.6 to 26 \\
\hline $\mathrm{Al}_{2} \mathrm{O}_{3}$ & 2.0 \\
\hline $\mathrm{Fe}$ (total) & 30 to 80 \\
\hline $\mathrm{CaO}$ & 0.5 to 1.5 \\
\hline $\mathrm{MgO}$ & 1.0 to 2.0 \\
\hline $\mathrm{Na}_{2} \mathrm{O}$ & 0.1 to 2 \\
\hline $\mathrm{SO}_{3}$ & 2 to 10 \\
\hline
\end{tabular}

For electron probe micro-analysis the sulphide sample was mounted in epoxy resin (cold mounting) and polished using conventional methods for electron microscopic studies. The polished section of of the sulphide was then examined and analysed with a JEOL, Super Probe JXA-8600 model electron microprobe operating with a current setting of $2 \times 10^{-8} \mathrm{~A}$ and with Standard Programme International (SPI) mineral standards, using on-line ZAF correction procedures. The major and minor elemental composition analyses of the sulphide phase from the Neyveli lignite deposit is reported in Table 2.

From the EPMA it can be inferred that the sulphide phase is nothing but marcasite and values show of $\mathrm{Fe}$ (45.617 to $47.324 \%)$ and S (51.878 to 52.829\%). Out of all thirteen marcasites grains analyzed only seven grains show significant amounts (0.004 to $0.080 \%)$ of gold content while $\mathrm{Cu}$ (0.003 to $0.018 \%), \mathrm{Pb}(0.020$ to $0.097 \%), \mathrm{Ni}(0.008$ to $0.034 \%), \mathrm{Zn}(0.005$ to $0.019 \%), \mathrm{Sb}$ ( 0.006 to $0.044 \%)$, Bi $(0.008$ to $0.382 \%)$, As $(0.097$ to $0.502 \%)$, Se $(0.004$ to $0.019 \%)$ and $\mathrm{Te}$ (0.011 to $0.014 \%)$ present sporadically and in traces. Recently Nayak et al., (2008) recorded occurrence of gold in the iron sulphide (pyrites/marcasite) associated with the high sulphur bearing tertiary coals of Northeast India. They concluded that the gold is lattice bound forming solid solutions within iron sulphides. The silicates present along with these Neyveli sulphide patches/marcasite were also analysed and reported in Table 3. The analyses of these silicates indicated that these are nothing but pure quartz. 
Table 2: EPMA analyses of marcasite from the Neyveli lignite deposit (wt.\%)

\begin{tabular}{|l|l|l|l|l|l|l|l|l|l|l|l|l|l|}
\hline & 1 & 2 & 3 & 4 & 5 & 6 & 7 & 8 & 9 & 10 & 11 & 12 & 13 \\
\hline $\mathrm{S}$ & 52.829 & 52.002 & 51.878 & 52.249 & 52.162 & 52.124 & 52.180 & 52.061 & 52.404 & 52.475 & 52.824 & 52.740 & 52.813 \\
\hline $\mathrm{Cu}$ & --- & 0.014 & --- & 0.013 & --- & 0.016 & -- & --- & -- & 0.003 & --- & 0.018 & 0.003 \\
\hline $\mathrm{Fe}$ & 45.960 & 45.802 & 45.794 & 45.617 & 46.153 & 46.301 & 46.866 & 47.275 & 46.975 & 46.832 & 47.199 & 47.324 & 47.184 \\
\hline $\mathrm{Bi}$ & 0.382 & --- & 0.341 & 0.057 & --- & 0.008 & --- & 0.340 & 0.042 & --- & 0.102 & --- & 0.243 \\
\hline $\mathrm{Ni}$ & --- & 0.014 & --- & --- & --- & 0.008 & --- & 0.034 & --- & 0.008 & --- & --- & --- \\
\hline $\mathrm{Pb}$ & 0.062 & 0.164 & 0.063 & 0.066 & 0.097 & --- & --- & --- & 0.020 & --- & 0.138 & 0.087 & --- \\
\hline $\mathrm{Sb}$ & 0.006 & --- & --- & 0.017 & --- & --- & 0.006 & 0.011 & 0.044 & 0.022 & --- & 0.040 & 0.021 \\
\hline $\mathrm{Zn}$ & --- & 0.014 & 0.019 & --- & --- & --- & --- & 0.011 & --- & --- & 0.005 & --- & 0.005 \\
\hline $\mathrm{Co}$ & 0.062 & 0.046 & 0.031 & 0.046 & 0.041 & 0.044 & 0.021 & 0.064 & 0.053 & 0.030 & 0.030 & 0.059 & 0.021 \\
\hline $\mathrm{Au}$ & 0.017 & --- & --- & --- & 0.040 & 0.004 & --- & 0.030 & 0.004 & --- & --- & 0.057 & 0.080 \\
\hline $\mathrm{As}$ & 0.104 & --- & 0.127 & --- & --- & 0.393 & 0.185 & 0.097 & 0.170 & 0.215 & 0.502 & 0.191 & --- \\
\hline $\mathrm{Se}$ & 0.019 & --- & 0.006 & --- & 0.013 & --- & --- & --- & 0.013 & 0.012 & --- & 0.004 & 0.011 \\
\hline $\mathrm{Te}$ & 0.014 & 0.011 & --- & 0.011 & --- & --- & --- & --- & --- & --- & --- & --- & --- \\
\hline $\mathrm{Total}$ & 99.456 & 98.066 & 98.259 & 98.074 & 98.507 & 98.807 & 99.258 & 99.923 & 99.725 & 99.597 & 100.800 & 100.519 & 100.388 \\
\hline
\end{tabular}

Table 3: EPMA analyses of the silicates present within the sulphides (wt.\%)

\begin{tabular}{|l|c|c|}
\hline Compounds & 1 & 2 \\
\hline $\mathrm{SiO}_{2}$ & 100.156 & 99.921 \\
\hline $\mathrm{FeO}$ & 0.153 & 0.137 \\
\hline $\mathrm{CaO}$ & 0.001 & 0.023 \\
\hline $\mathrm{K}_{2} \mathrm{O}$ & ----- & 0.008 \\
\hline $\mathrm{TiO}_{2}$ & ---- & 0.009 \\
\hline $\mathrm{Cr}_{2} \mathrm{O}_{3}$ & 0.005 & 0.009 \\
\hline $\mathrm{NiO}$ & ----- & 0.019 \\
\hline $\mathrm{V}_{2} \mathrm{O}_{5}$ & 0.001 & 0.001 \\
\hline Total & 100.317 & 100.129 \\
\hline
\end{tabular}

\section{DISCUSSION AND CONCLUSIONS}

The variation of chemical composition in the present marcasite analysis may be attributed to its origin in a lignite province. It can be inferred that these sulphide patches of Neyveli lignite deposit mostly syngenetic with coal. The gold concentration in these sulphides may be by biological activity and/or by inorganic adsorption process during recrystallization in a reducing environment. 17 million tones of lignite are excavated annually from this deposit (Kompella and 
Raghuthaman, 2002). Out of which around 325 tonnes of sulphide will be accumulated annually at the rate of $1.97 \%$ of sulphide boulders from the lignite run of mine sample. In view of this, it may be worth studying these sulphides for resources development of marcasite in general and gold in particular. As it is known that most of the mining industries wastes contain useful materials and if recovered economically and in an environmental friendly way it adds up to the revenue of the mining company. In this contest, utilization of these sulphides, from the lignite mine of Neyveli not only essential from resource conservation/utilization but also from environmental point of view. Hence, if the sulphides patches are studied in detail then the sulphides which are dumped as waste can be a source of gold.

\section{ACKNOWLEDGEMENTS}

The samples were collected by Dr. R. Nagendra and Dr.E. Rasool Mohideen. The authors (RN and ERM) are thankful to the authorities of Neyveli Lignite Corporation for permission as well as helps during collection of marcasite samples from Neyveli mine. The authors are also thankful IIC, IIT, Roorkee for EPMA work.

\section{REFERENCES}

Banerjee, D., Mandal, P.K., Nithyananthan, N., Thakur, J,S. and Hirani, M. (1997) Effect of different forms of sulphur on coal combustion. R \& D Journal (NTPC), V.3, No.1, pp.37-42.

Kompella, R.M. and Raghuthaman, S. (2002) Removal of marcasite from lignite. Proc. of the Int. Sem. on Mineral Processing Technology (Eds. S.Subramanian, K.A..Natarajan, B.S.Rao and T.R.R.Rao), 3-5 January 2002, V.2, pp.638-643.

Nayak, B., Chakravarty, S and Bhattacharyya, K.K. (2008) Invisible gold in the high sulphur Tertiary coals of Northeast India. Current Science, V.95, No.9, pp.1334-1337. 